\title{
Efficacy of Biocontrol Agents Beauveria bassiana and Plant Extracts on Dactylopius opuntiae Cockerell (Hemiptera: Dactylopiidae)
}

\author{
L. G. Oliveira ${ }^{1}$, Rosineide S. Lopes ${ }^{1}$, Venézio Felipe dos Santos ${ }^{1}$, Elza Aurea Luna-Alves Lima ${ }^{2}$, \\ Elizabeth A. A. Maranhão ${ }^{1} \&$ Antonio F. da Costa $^{1}$ \\ ${ }^{1}$ Agronomic Institute of Pernambuco, Recife, PE, Brazil \\ ${ }^{2}$ Department of Mycology, Federal University of Pernambuco, Recife, PE, Brazil \\ Correspondence: L. G. Oliveira, Agronomic Institute of Pernambuco (IPA), Av. General San Martin, 1371, Bongi, \\ 50761-000, Recife, PE, Brazil. Tel: 55-81-2126-8540. E-mail: lugoliveira@yahoo.com.br
}

Received: May 27, 2019 Accepted: August 11, $2019 \quad$ Online Published: December 15, 2019

doi:10.5539/jas.v12n1p171 URL: https://doi.org/10.5539/jas.v12n1p171

The research is financed by National Council for Scientific and Technological Development (CNPq).

\begin{abstract}
Opuntia ficus-indica is a cactus used as fodder for animals in arid areas worldwide. However, the palm is parasitized by the carmine cochineal scale insect (Dactylopius opuntiae) causing great damage to cactus plantations in the semi-arid region of Brazil. Leaf extracts aqueous and hydro-ethanolic of neem and citronella at concentrations of 50, 100 and $200 \mathrm{mg} / \mathrm{mL}$, and strains suspensions of Beauveria bassiana $\left(1 \times 10^{8}\right.$ conidia/mL); were applied on cladodes infested by $D$. opuntiae, in the laboratory. After 10 days of treatment, the percentages of mortality were obtained on the adult females. Then, the most efficient extracts were selected in the laboratory tests for control tests in palm plantation, where $100 \mathrm{~mL}$ of the extracts were applied in the $100 \mathrm{mg} / \mathrm{mL}$ concentration on cladodes of palms. The results show that B. bassiana strains were not pathogenic to D. opuntiae. Only the aqueous and hydro-ethanolic neem extracts were effective in controlling the cochineal. We conclude that neem extracts are effective against $D$. opuntiae and can be used to control carmine scale in Opuntia ficus-indica in the field.
\end{abstract}

Keywords: entomopathogenic fungi, plant extracts, carmine cochineal, neem, citronella

\section{Introduction}

Opuntia ficus-indica (L.) Mill. (Caryophyllales: Cactaceae) is a cactus of great importance in the economic development of the arid and semi-arid areas of Brazil, Mexico, United States, Portugal, Italy and the countries of the Middle East where it is widely used as a source of food and water. The nutritional and pharmaceutical importance of $O$. ficus-indica is due to the high levels of soluble carbohydrates, calcium, iron, copper, sodium, potassium, phenolic acids and vitamins (Santos et al., 2006; Chougui et al., 2013; Pretti, Bazzu, Serra, \& Nieddu, 2014; Santos, R. L. S. Oliveira, Costa, Tiago, \& N. T. Oliveira, 2015).

Carmine cochineal, Dactylopius opuntiae (Cockerell) (Hemiptera: Coccoidea) is used in Peru, the Canary Islands and Mexico for the production of carmine dyes in the food industry and for the biological control of some invasive cacti (Hoffmann, Moran, \& Zimmermann, 1999; Paterson et al., 2011). However, cochineal also parasitizes species of cacti including O. ficus-indica. In Brazil and Mexico the insect threatens cultivars of this plant causing losses in the production of fodder and fruits, with enormous economic consequences for farmers and ranchers (Santos et al., 2006; Chavez-Moreno, Tecante, \& Casas, 2009; Lopes et al., 2018). The use of insecticides in the control of large infestation foci of carmine cochineal as well as the use of insect-resistant palm cultivars is, therefore, recommended in order to maintain infestation at a level that does not damage crop productivity significantly (Santos et al., 2006; Falcão, Oliveira, Mergulhão, Silva, \& Santos, 2013). However, the increased use of chemical insecticides is of mounting concern due to contamination of soil, water sources and air (St. Leger \& Wang, 2010). Therefore, new, more efficient and safer alternatives are recommended such as biological control of pests by entomopathogenic fungi or the spraying of plant extracts (Svedese, Tiago, Bezerra, Paiva, Alves-Lima, \& Porto, 2013; Lopes, G. Lima, Costa, Luna-Alves-Lima, \& V. L. M. Lima, 2017; Lopes et al., 2018). These 
methods promote the maintenance and balance of insect populations, limiting their rapid multiplication without damaging other organisms and the environment (Lv et al., 2011; Sabbour \& Abdel-Rahman, 2013).

Beauveria bassiana (Bals.) Vuillemin is an important entomopathogenic fungus used as a pest biocontrol agent due to its wide geographic distribution, host diversity (occurring in more than 200 species) and pathogenicity on several species of pest insects (Alves, 1998; Zhang et al., 2009, Jin et al., 2010). The action of B. bassiana strains has been confirmed in the control of several insects, among them, Scalebacterium texensis (Tinsley), Praelongorthezia praelonga (Douglas), Planococcus citri (Risso) and Planococcus ficus (Signoret) (Andaló, Moino Júnior, Santa-Cecilia, \& Souza, 2004; Benvenga, Gravena, Silva, Junior, \& Amorim, 2011; Kulkarni \& Patil, 2013; Mohamed, 2016).

Plants produce substances that are harmless to humans and the environment and are considered alternative sources for the discovery of natural insecticides (Luna et al., 2005). These substances are more beneficial than chemicals, since they are renewable, easily degradable and do not pollute the environment (Oliveira, Lins-Neto, Araújo, \& Albuquerque, 2007). Thus, several plant species such as neem (Azadirachta indica A. Juss), and citronella (Cymbopogon winterianus Jowitt) have been tested successfully in insect control. Considering the economic damage caused by $D$. opuntiae the search for natural insecticides for the control of cochineal is recommended. In this context, the objective of this work was to analyze the potential of B. bassiana and extracts of neem and citronella in the control of D. opuntiae.

\section{Method}

\subsection{Insect Collection and Rearing}

The cochineal D. opuntiae were collected from plantations of $O$. ficus-indica in the municipalities of Sertão do Moxotó and Pajeú, Pernambuco State, Brazil. The insects were raised in acclimatized chambers at $28 \pm 1{ }^{\circ} \mathrm{C}$, with $37 \pm 3 \%$ relative humidity $(\mathrm{RH})$, and $12 \mathrm{~h}$ photoperiod, on healthy cactus cladodes placed horizontally on wooden supports and infested with first instar nymphs. The bioassays used adult females of $D$. opuntiae after 40 days of infestation, according to the duration of the biological cycle of D. opuntiae (Flores-Hernández et al., 2006). The cladodes with adult females were sprayed with a $2 \%$ solution of detergent before assay to improve contact of the suspensions with the insect bodies.

\subsection{Beauveria Bassiana Strains Used in the Bioassays}

The strains of B. bassiana (URM2926, URM2921, URM2933, URM2935, URM2929, URM2916 and URM2912) were obtained from the URM Culture Collection (WDCM604) of the Federal University of Pernambuco (UFPE); B. bassiana (IPA202, IPA223 and IPA226) were obtained from the Culture Collection of Agronomic Institute of Pernambuco (IPA). The ten fungal strains were cultivated on Potato-Dextrose-Agar medium (PDA) for 12 days, and their viability determined by per cent germination tests after reinsulation from infected adult females. The fungal suspensions were made by the inoculation of the conidia in $10 \mathrm{~mL}$ of Tween 80 solution $(0.1 \%)$, and these were quantified in a Neubauer's chamber. The suspensions were adjusted to a concentration of $1 \times 10^{8} \mathrm{conidia} / \mathrm{mL}$ by successive dilutions of $1 \mathrm{~mL}$ of fungal suspensions in $9 \mathrm{~mL}$ of the Tween-80 solution $(0.1 \%)$, and subsequent quantification of the concentration of conidia in the Neubauer's chamber.

\subsection{Pathogenicity of Beauveria bassiana on Dactylopius opuntiae in Laboratory}

Palms infested with adult females were sprayed with $10 \mathrm{~mL}$ of the suspension $\left(1 \times 10^{8}\right.$ conidia $\left./ \mathrm{mL}\right)$ of each $B$. bassiana strain and $0.1 \%$ Tween 80 (control) using a De Vilbiss No. 15 hand sprayer. The palms were placed in rectangular plastic pots, measuring approximately $30 \mathrm{~cm} \times 15 \mathrm{~cm} \times 8 \mathrm{~cm}$, and kept in an air-conditioned room at a temperature of $26 \pm 1{ }^{\circ} \mathrm{C}$. The evaluations were done 10 days after the application of the treatments. Fifty adult females were collected from squares of the palm with dimensions of $64 \mathrm{~cm}^{2}(8 \mathrm{~cm} \times 8 \mathrm{~cm})$. The experiment was performed in triplicate and involved 11 treatments (10 strains and control), totalling 150 adult females per treatment. Mortality analysis was performed under a stereomicroscope. Dead insects were identified by modification in coloration, a dehydrated/flaccid body and the absence of movement. Confirmation of the mortality of the insects by the fungi tested was performed as described by Alves (1998). The females were disinfected in alcohol (70\%), sodium hypochlorite (4\%) and successive washes in autoclaved distilled water. The insects were transferred to incubator (BOD) at a temperature of $26 \pm 1{ }^{\circ} \mathrm{C}$ and humidity of $80 \pm 10 \% \mathrm{RH}$ until growth and fungal sporulation was observed.

\subsection{Preparation of Vegetable Extracts}

Neem and citronella leaves were collected from plants located at IPA, later washed with distilled water, dried at room temperature and crushed. The extracts were then subjected to two processes of aqueous extraction at $100{ }^{\circ} \mathrm{C}$ 
and to the hydroalcoholic extraction (70\%) for two hours. The hydro-ethanolic extract was maintained at a temperature of $45{ }^{\circ} \mathrm{C}$ for 16 hours for evaporation of the alcohol.

\subsection{Effect of the Plant Extracts on Dactylopius opuntiae}

For the D. opuntiae bioassays, cladodes infested with adult females were sprayed with $10 \mathrm{~mL}$ of the extract concentrations $\left(50,100\right.$ and $200 \mathrm{mg} / \mathrm{mL}$ ), and with Tween $80(0.1 \%)$ solution (control) using a De Vilbiss $\mathrm{n}^{\circ} 15$ manual sprayer. After spraying, the cladodes were placed in container $(30 \mathrm{~cm} \times 15 \mathrm{~cm} \times 8 \mathrm{~cm})$ and maintained at room temperature $\left(28 \pm 1{ }^{\circ} \mathrm{C}\right)$ and $37 \pm 3 \%$ relative humidity for 10 days and then 50 adult females were collected from $64 \mathrm{~cm}^{2}$ of each palm $(8 \mathrm{~cm} \times 8 \mathrm{~cm})$, according to Lopes, Oliveira, Costa, Correia, Luna-Alves Lima, and Lima (2018). The experiments were performed in triplicate, totaling 150 females per treatment. The mortality counts were made using a stereomicroscope: dead insects had distinctive color modifications, dehydrated or flaccid bodies, or were immobile.

\subsection{Action of the Plant Extracts on Dactylopius opuntiae in Plants of Opuntia ficus-indica}

The field experiment was carried out in the municipality of São Bento do Una (Pernambuco/Brazil) on a private property with a plantation of forage palm infested with cochineal. For each treatment a plant with a uniform infestation incidence and spacing of $10 \mathrm{~m}$ between plants was used. The extracts $(100 \mathrm{mg} / \mathrm{mL})$ were applied by hand spraying $100 \mathrm{~mL}$ of the suspensions on the cladodes of the palms. In the control treatment, spraying was performed only with Tween $80(0.01 \%)$ solution. After 15 days, three cladodes of each sprayed palm were collected and analyzed at the Biological Control Laboratory/IPA. In each cladode, 50 females were selected in a quadrant of $64 \mathrm{~cm}^{2}(8 \times 8 \mathrm{~cm})$, totaling 150 insects per fungal lineage and per extract used. To confirm the mortality of the insects by the extracts, the body texture and the dye of the cochineal females were observed.

\subsection{Statistical Analysis}

The experimental design was completely randomized. The statistical analysis of the data was performed using the analysis of variance (ANOVA) and the means were compared by the Tukey test at $5 \%$ probability level using the SAS Proc. ANOVA (SAS Institute, 1999-2001) program.

\section{Results}

Ten strains of $B$. bassiana were analyzed for in vitro pathogenicity on carmine cochineal. They were not pathogenic, causing mortality rates ranging from 2 to $10 \%(\mathrm{p}=0.05)$. B. bassiana IPA202 caused death of $10.67 \%$ of adult females (Table 1).

Table 1. Confirmed mortality of adult females of Dactiylopius opuntiae after 10 days of infection by Beauveria bassiana strains

\begin{tabular}{ll}
\hline Strains & Mortality (\%) \\
\hline Beauveria bassiana IPA 202 & $10.67 \mathrm{a}$ \\
Beauveria bassiana URM2935 & $4.67 \mathrm{~b}$ \\
Beauveria bassiana URM2933 & $4.00 \mathrm{bc}$ \\
Beauveria bassiana URM2926 & $2.67 \mathrm{bc}$ \\
Beauveria bassiana URM2912 & $2.00 \mathrm{bc}$ \\
Beauveria bassiana IPA226 & $2.00 \mathrm{bc}$ \\
Beauveria bassiana URM2929 & $0.00 \mathrm{c}$ \\
Beauveria bassiana IPA 223 & $0.00 \mathrm{c}$ \\
Beauveria bassiana URM2921 & $0.00 \mathrm{c}$ \\
Control & $0.00 \mathrm{c}$ \\
\hline
\end{tabular}

Note. Means followed by different letters in the column are significantly different by the Tukey test at $5 \%$.

Table 2 shows the action of the extracts of neem and citronella in the control of adult females of D. opuntiae in the laboratory. The aqueous and hydro-ethanolic extracts of neem had a positive effect on the mortality of adult females at the concentrations tested, resulting in the death of 42 to $82 \%$ of the cochineal. This differed significantly from the control treatment with a mortality rate of $1.3 \%(\mathrm{p}=0.05)$. Insect control became more efficient with increasing concentrations, except for the aqueous extract of neem at a concentration of $100 \mathrm{mg} / \mathrm{mL}(\mathrm{p}=0.05)$. Citronella extracts showed no insecticidal potential on adult females, with a mean mortality ranging from $4.7 \%$ to $8.7 \%$, with no statistical difference between extracts, concentrations or the control treatment $(p=0.05)$. 
Table 2. Mortality of adult females of Dactiylopius opuntiae after 10 days of treatment with extracts of Azadirachta indica and Cymbopogon winterianus

\begin{tabular}{llll}
\hline \multirow{2}{*}{ Extract } & Concentration $(\mathrm{mg} / \mathrm{mL})$ & \multicolumn{2}{c}{ Mortality $(\%)$} \\
\cline { 3 - 4 } & & Aqueous extract & Hydroethanolic extract \\
\hline \multirow{3}{*}{ Neem } & 50 & $1.30 \mathrm{~d}$ & $1.30 \mathrm{~b}$ \\
& 100 & $59.33 \mathrm{~b}$ & $60.00 \mathrm{a}$ \\
& 200 & $42.00 \mathrm{c}$ & $72.00 \mathrm{a}$ \\
\multirow{3}{*}{ Citronella } & Control & $82.00 \mathrm{a}$ & $72.00 \mathrm{a}$ \\
& 50 & $1.30 \mathrm{~b}$ & $1.30 \mathrm{~b}$ \\
& 100 & $5.33 \mathrm{a}$ & $4.67 \mathrm{a}$ \\
& 200 & $6.00 \mathrm{a}$ & $8.67 \mathrm{a}$ \\
\hline
\end{tabular}

Note. Means followed by different letters in the column are significantly different by the Tukey test at $5 \%$.

Table 3 shows the bio-insecticidal effect of the plant extracts on adult females in the field condition. The aqueous and hydro-ethanolic extracts of neem inflicted a mortality rate of $88 \%$ and $97 \%$ respectively, whereas $25 \%$ of adult female cochineal in the control treatment died $(\mathrm{P}=0.05 \%)$. The extracts of citronella were not effective in the control of the adult females causing the death of only $8 \%$ of the insects.

Table 3. Mortality of adult females of Dactiylopius opuntiae after 10 days of treatment with extracts of Azadirachta indica and in the field

\begin{tabular}{ll}
\hline Different extraction methods & Mortality (\%) \\
\hline Control & $25.00 \mathrm{~b}$ \\
Aqueous extract & $88.00 \mathrm{a}$ \\
Hydroethanolic extract & $97.00 \mathrm{a}$ \\
\hline
\end{tabular}

Note. Means followed by different letters are significantly different from each other by the Tukey test at $5 \%$ probability.

\section{Discussion}

Previous studies have found that B. bassiana and Beauveria sp strains were efficient in controlling D. texensis and P. praelonga cochineal, respectively, causing high percentages of mortality (50 to 65\%) (Andaló, Moino Júnior, Santa-Cecilia, \& Souza, 2004). In contrast the results of this study found that several strains of B. bassiana were not pathogenic or only caused low levels of $D$. opuntiae mortality.

The control of the insect can be intensified by the application of multiple $B$. bassiana strains or their association with compatible insecticide formulations (Benvenga, Gravena, Silva, Junior, \& Amorim, 2011). Kulkarni and Patil (2013) verified the efficiency of Verticillium lecanii Viegas and B. bassiana in P. citri cochineal control. Similarly, Mohamed (2016) reported the pathogenicity of B. bassiana, Metarhizium anisopliae (Metchnikoff) Sorokin and $V$. lecanii on adult Planococcus ficus (Signoret) cochineal. In this case, B. bassiana was the most efficient fungus, as it caused the death of $98 \%$ of insects and presented the lowest values of $\operatorname{LC}_{50}\left(6 \times 10^{4}\right.$ conidia/mL $)$ and $\mathrm{TL}_{50}(5.30$ days) in relation to the other fungi.

The low efficiency of $B$. bassiana on adult females of $D$. opuntiae can be explained by the small or nonexistent specificity and virulence of the fungus. Dactylopius species have a layer of wax that covers the body and canmay difficult contact with aqueous solutions (Nobel, 2001). Fungal infection begins with the hydrophobic adhesion of the conidia on the surface of the host. Then, specific enzymes degrade the cuticle and penetrate the body of the insect (Alves, 1998; Fang, Pava-ripoll, Wang, \& St. Leger, 2009). According to Svedese et al. (2013), the production of these enzymes by $B$. bassiana is influenced by specific components of the host cuticle and there is a relationship between the between this production and the pathogenicity of the fungus. So the waxy layer may prevent chemicals from reaching the integument (Demirci, Mustu, Kaydan, \& Ülgentürk, 2011).

Probably, Neem plant extracts killed the adult females of $D$. opuntiae at the tested concentrations, whereas the citronella extracts did not cause significant mortality. Neem extracts caused degradation of the waxy layer that 
covers the adult female $D$. opuntiae followed by dehydration and death of insect. Biodegradable products tested in the control of $D$. opuntiae, such as detergents and plant extracts, also contain specific substances that can degrade the waxy layer that protects the insect, causing dehydration and death of the cochineal (Nobel, 2001; Flores-Hernández et al., 2006, Vigueras, Tovar, \& Pelayo-Ortiz, 2009, Lopes, Oliveira, Costa, Correia, Lima, \& Lima, 2018).

The hydro-ethanolic extract of neem was more efficient in the control of cochineal, causing the death of $60 \%$ and $72 \%$ in the lower concentrations, respectively. The aqueous extract was effective in the control of the insect, while both extracts of citronella resulted in an average mortality of less than $10 \%$. However, Vázquez-García, Garabito-Espinoza, Tabares-Vega, and Castillo-Herrera (2011) reported that essential oils of plants Ocimum basilicum L., Mentha spicata L., C.winterianus (Jowitt) and Lippia graveolens Kunth were toxic to the first instar nymphs of D. opuntiae. Vigueras, Tovar, and Pelayo-Ortiz (2009) tested the extracts of Chenopodium ambrosioides L., Mentha piperita L., Mentha viridis L., Tagetes erecta L., and T. florida Sweet on D. opuntiae. They found that the extracts caused the death of 35 to $98 \%$ of nymphs and adult females, respectively, suggesting that this toxicity might be due to the presence of terpenoids. For example, the commercial terpenoids Eugenol $99 \%$ (Across Organics, Mexico), 1,8-Cineol 99\% and Mentol 99\% (Sigma Aldrich, Mexico) significantly reduced the fixation of the cochineal on the cladodes of the palm and act as insect repellents (Pérez-Ramirez, Castrejón-Ayala, \& Jiménez-Pérez, 2014). The aqueous and hydro-ethanolic extracts of Ricinus communis L. and Poincianella pyramidalis (Tul.) L. P. Queiroz, at concentrations of 5, 10 and 20\% caused death rates from 61.23 to $100 \%$ on female D. opuntiae (Santos, Oliveira, Costa, Tiago, \& Oliveira, 2015). Lopes, Oliveira, Costa, Correia, Luna-Alves Lima, and Lima (2018) found that extracts of Libidibia ferrea var. ferrea and Agave sisalana were efficient in controlling nymphs and adult females of D. opuntiae, causing mortality rates between 51 and $97 \%$.

The action of neem extracts as pest control agents is related to the complexity of their chemical components. Among them, azadirachtin is an important pest control agent in agriculture, as it does not affect non-target organisms, is compatible with other control agents and can be used in Integrated Pest Management (Mossini \& Kemmelmeier, 2005). The insecticidal activity of neem extracts may be related to the presence of these secondary metabolites (Omena et al., 2007; Souza \& Trovão, 2009). In this sense, Gorlach-Lira and Lira (2011) evaluated the bioinsecticidal action of neem oil on $D$. opuntiae in palm plantations, at concentrations of 1,2 and $3 \%$, and observed that the oil significantly reduced the population of insects on the cladodes. Similarly, Borges et al. (2013) showed that neutral detergent, cassava starch, liquid waste generated from the processing of cassava, mineral oil and neem were the most efficient for the control of cochineal carmine.

In the field, aqueous and hydro-ethanolic neem extracts killed adult females with mortality rates of 97 and $88 \%$, respectively. Similar results were found by Vigueras, Tovar, and Pelayo-Ortiz (2009) when testing extracts of Chenopodium ambrosioides L., Mentha piperita L., M. viridis L., Tagetes erecta L., and T. florida Sweet on D. opuntiae in field experiments. The extract of $T$. erecta promoted the death of more than $90 \%$ of the nymphs and adult females. Silva, Mergulhão, Medeiros, Figueiredo, and Burity (2013) verified the action of extracts of plants from the Caatinga on D. opuntiae in palm plantations in Pernambuco. In this work, extracts of Cynophalha flexiosa (L.) J. Presl in F. Berchtold and J. S. Presl, Prir. Rostlin were more efficient and caused mortality rates higher than 50\%. Lopes, Oliveira, Costa, Correia, Luna-Alves Lima, and Lima (2018) reported that the aqueous and methanolic extracts of the leaves and pods of Libidibia ferrea var. ferrea (Mart. Ex Tul.) L. P. Queiroz (= Caesalpinia ferrea) and the hydroxylic extract of the leaves of Agave sisalana Perrine ex Engelm were efficient on the adult females of $D$. opuntiae, causing mortality from 72.46 to $99.33 \%$ on plantations of $O$. ficus-indica .

There are few studies on the use of substances or extracts based on neem in the control of D. opuntiae in the field. Lopes, Albuquerque, Brito, and Batista (2009) verified the effect of Prev-Am (Sodium tetraborahydrate decahydrate) orange oil on D. opuntiae, in a giant palm plantation in the municipality of Monteiro (Paraíba State). The product caused the death of nymphs and adult insects, with highest efficiency at concentrations of 0.6 and $0.7 \%$, respectively. Gorlach-Lira and Lira (2011) evaluated the action of neem oil at concentrations of 1,2 and $3 \%$ on $D$. opuntiae in cladodes after 21 days, which caused the elimination of most of the colonies and were effective in controlling the cochineal in the studied region. Lacerda et al. (2011) analysed the seed oil of neem (1 and 2\%), mineral oil (2\%) and the maipueira's liquid (50 and 100\%) of Manihot esculenta Crantz on carmine cochineal vegetation house. Neem $(2 \%)$ and mineral oil $(2 \%)$ reduced the infestation by 10 and $91.6 \%$, respectively, while the manioc extracts decreased infestation by 54.16 and $62.50 \%$.

\section{Conclusions}

The Beauveria bassiana strains tested are not pathogenic to adult D. opuntiae females, not being indicated for the control of the insects. Citronella (aqueous and hydro-ethanolic) extracts are ineffective in controlling D. opuntiae 
in laboratory tests. Aqueous and hydro-ethanolic neem extracts are efficient in controlling D. opuntiae in laboratory and field tests, promoting mortality rates between 72 and $97 \%$ of adult females. These extracts can be used in the control of carmine cochineal in emanations of $O$. ficus-indica in the world semi-arid regions.

\section{Acknowledgements}

The authors thank the Brazilian agency National Council for Scientific and Technological Development (CNPq) (CNPq; grant No. 314082/2009-3), and Banco do Nordeste do Brasil (BNB) for their financial support to this research.

\section{References}

Alves, S. B. (1998). Fungos entomopatogênicos. In S. B. Alves (Ed.), Controle Microbiano de Insetos (2nd ed., pp. 289-371). Piracicaba: FEALQ.

Andaló, V., Moino Júnior, A., Santa-Cecilia, L. V. C., \& Souza, G. C. (2004). Seleção de isolados de fungos e nematóides entomopatogênicos para a cochonilha-da-raiz-do-cafeeiro Dysmicoccus texensis (Tinsley). Arquivos do Instituto Biológico, 71(2), 181-187. Retrieved from http://www.biologico.sp.gov.br/uploads/ docs/arq/V71_2/andalo.PDF

Benvenga, S. R., Gravena, S., Silva, J. L., Junior, N. A., \& Amorim, L. C. S. (2011). Manejo prático da cochonilha ortézia em pomares de citros. Citrus Research \& Technology, 32(1), 39-52. https://doi.org/ $10.5935 / 2236-3122.20110005$

Borges, L. R., Santos, D. C., Cavalcanti, V. A. L. B., Gomes, E. W. F., Falcão, H. M., \& Silva, D. M. P. (2013). Selection of cactus pear clones regarding resistance to carmine cochineal Dactylopius opuntiae (Dactylopiidae). Acta Horticulturae, 995, 359-365. https://doi.org/10.17660/ActaHortic.2013.995.47

Chavez-Moreno, C. K. A., Tecante, A., \& Casas, E. A. (2009). The Opuntia (Cactaceae) and Dactylopius (Hemiptera: Dactylopiidae) in Mexico: A historical perspective of use, interaction and distribution. Biodiversity and Conservation, 18(13), 3337-3355. https://doi.org/10.1007/s10531-009-9647-X

Chougui, N., Tamendjari, A., Hamidj, W., Hallal, S., Barras, A., Richard, T., \& Larbat, R. (2013). Oil composition and characterization of phenolic compounds of Opuntia ficus-indica seeds. Food Chemistry, 139(1-4), 796-803. https://doi.org/10.1016/j.foodchem.2013.01.054

Demirci, F., Mustu, M., Kaydan, M. B., \& Ülgentürk, S. (2011). Laboratory evaluation of the effectiveness of the entomopathogen; Isaria farinosa, on citrus mealybug, Planococcus citri. Journal of Pest Science, 84(3), 337-342. https://doi.org/10.1007/s10340-011-0350-9

Falcão, H. M., Oliveira, M. T., Mergulhão, A. C., Silva, M. V., \& Santos, M. G. (2013). Ecophysiological performance of three Opuntia ficus-indica cultivars exposed to carmine cochineal under field conditions. Scientia Horticulturae, 150(4), 419-424. https://doi.org/10.1016/j.scienta.2012.11.021

Fang, W., Pava-Ripoll, M., Wang, S., \& St. Leger, R. J. (2009). Protein kinase A regulates production of virulence determinants by the entomopathogenic fungus, Metarhizium anisopliae. Fungal Genetics and Biology, 46(3), 277-285. https://doi.org/10.1016/j.fgb.2008.12.001

Flores-Hernández, A., Murillo-Amador, B., Rueda-Puente, E. O., Salazar-Torres, J. C., García-Hernández, J. L., \& Troyo-Diéguez, E. (2006). Reproduction of wild cochineal Dactylopius opuntiae (Homoptera: Dactylopiidae). Revista Mexicana de Biodiversidad, 77(1), 97-102. https://doi.org/10.22201/ib.20078706e. 2006.001.321

Gorlach-Lira, K., \& Lira, B. B. (2011). Utilização do óleo nim para o controle da cochonilha-do-carmim Dactylopius opuntiae (Cockerell) em palma-forrageira. Pesquisa Agropecuária Pernambucana, 16(Especial), 18-22.

Hoffmann, J. H., Moran, V. C., \& Zimmermann, H. G. (1999). Integrated management of Opuntia stricta (Haworth) Haworth (Cactaceae) in South Africa: An enhanced role for two, renowned, insect agents. African Entomology Memoir, 1, 15-20.

Jin, K., Zhang, Y., Fang, W., Luo, Z., Zhou, Y., \& Pei, Y. (2010). Carboxylate Transporter Gene JEN1 from the entomopathogenic fungus Beauveria bassiana is involved in conidiation and virulence. Applied and Environmental Microbiology, 76(1), 254-263. https://doi.org/10.1128/AEM.00882-09

Kulkarni, S. R., \& Patil. S. K. (2013). Efficacy of different biopesticides and insecticides against mealy bugs on custard apple. Pest Management in Horticultural Ecosystems, 19(1), 113-115. Retrieved from http://aapmhe.in/index.php/pmhe/article/download/178/170 
Lacerda, C. A., Santos, V. F., Borges, L. S., Santos, E. A., Costa, E. K. S. L., Silva-Filho, C. A. T., ... Silva, D. M. P. (2011). Utilização de produtos alternativos para o controle da cochonilha-do-carmim Dactylopius opuntiae (Cockerell) em palma-forrageira. Pesquisa Agropecuária Pernambucana, 16(Especial), 31-41.

Lopes E. B., Albuquerque I. C., Brito C. H., \& Batista J. L. (2009). Velocidade de dispersão de Dactylopius opuntiae em palma gigante (Opuntia ficus-indica). Revista Engenharia Ambiental, 6(1), 644-649. Retrieved from http://ferramentas.unipinhal.edu.br/engenhariaambiental/viewarticle.php?id=188\&layout=abstract

Lopes, R. S., Lima, G., Correia, M. T. S., Costa, A. F., Luna-Alves-Lima, E. A., \& Lima, V. L. M. (2017). The potential of Isaria spp. as a bioinsecticide for the biological control of Nasutitermes corniger. Biocontrol Science and Technology, 27(9), 1038-1048. https://doi.org/10.1080/09583157.2017.1380163

Lopes, R. S., Oliveira, L. G., Costa, A. F., Correia, M. T., Luna-Alves-Lima, E. A., \& Lima, V. L. M. (2018). Efficacy of Libidibia ferrea var. ferrea and Agave sisalana extracts against Dactylopius opuntiae (Hemiptera: Coccoidea). Journal of Agricultural Science, 10(4), 255-267. https://doi.org/10.5539/ jas.v10n4p255

Luna, J. S., Santos, A. F., Lima, M. R. F., Omena, M. C., Mendonça, F. A. C., Bieber, L. W., ... Santana, A. E. G. (2005). A study of the larvicidal and molluscicidal activities of some medicinal plants from Northeast Brazil. Journal of Ethnopharmacology, 97(2), 199-206. https://doi.org/10.1016/j.jep.2004.10.004

Lv, J., Wilson, L. T., Beuzelin, J. M., White, W. H., Reagan, T. E., \& Way, M. O. (2011). Impact of Cotesia flavipes (Hymenoptera: Braconidae) as an augmentative biocontrol agent for the sugarcane borer (Lepidoptera: Crambidae) on rice. Biological Control, 56(2), 159-169. https://doi.org/10.1016/j.biocontrol. 2010.10.005

Marques, R. P., Monteiro, A. C., \& Pereira, G. T. (2004). Crescimento, esporulação e viabilidade de fungos entomopatogênicos em meios contendo diferentes concentrações do óleo Nim (Azadirachta indica). Ciência Rural, 34(6), 1675-1689. https://doi.org/10.1590/S0103-84782004000600002

Mohamed, G. S. (2016). Virulence of entomopathogenic fungi against the vine mealy bug, Planococcus ficus (Signoret) (Hemiptera: Pseudococcidae). Egyptian Journal of Biological Pest Control, 26(1), 47-51.

Mossini, S. A. G., \& Kemmelmeier, C. (2005). A árvore Nim (Azadirachta indica A. Juss): múltiplos usos. Acta Farmacéutica Bonaerense, 24(1), 139-148. Retrieved from http://www.latamjpharm.org/trabajos/24/1/ LAJOP_24_1_7_1_3E9IR6431G.pdf

Nobel, P. S. (2001). Ecophysiology of Opuntia ficus-indica. In C. Mondragón-Jacobo \& S. Pérez-González (Eds.), Cactus (Opuntia spp.) as forage (pp. 13-20). Rome: Food and Agriculture Organization of the United Nations (FAO). Retrieved from http://www.fao.org/docrep/005/Y2808E/y2808e06.htm

Oliveira, R. L. C., Lins-Neto, E. M. F., Araújo, E. L., \& Albuquerque, U. P. (2007). Conservation priorities and population struture of woody medicinal plants in an area of Caatinga vegetation (Pernambuco State, NE Brazil). Environmental Monitoring and Assessment, 132(1-3), 189-206. https://doi.org/10.1007/s10661006-9528-7

Omena, M. C., Navarro, D. M. A. F., Paula, J. E., Luna, J. S., Lima, M. R. F., \& Santana, A. E. G. (2007). Larvicidal activities agaisnst Aedes aegypti of some Brazilian medicinal plants. Bioresource Technology, 98(13), 2549-2556. https://doi.org/10.1016/j.biortech.2006.09.040

Paterson, I. D., Hoffmann, J. H., Klein, H., Mathenge, C. W., Neser, S., \& Zimmermann, H. G. (2011). Biological control of Cactaceae in South Africa. African Entomology, 19(2), 230-246. https://doi.org/ $10.4001 / 003.019 .0221$

Pérez-Ramirez, A., Castrejón-Ayala, F., \& Jiménez-Pérez, A. (2014). Potential of terpenoids and mealybug extract to deter the establishment of Dactylopius opuntiae (Hemiptera: Dactylopiidae) crawlers on Opuntia ficus-indica. Florida Entomologist, 97(1), 269-271. https://doi.org/10.1653/024.097.0137

Pretti, L., Bazzu, G., Serra, P. A., \& Nieddu, G. (2014). A novel method for the determination of ascorbic acid and antioxidant capacity in Opuntia ficus-indica usang in vivo microdialysis. Food Chemistry, 147, 131-137. https://doi.org/10.1016/j.foodchem.2013.09.120

Sabbour, M. M., \& Abdel-Rahman, A. (2013). Efficacy of isolated Nomuraea rileyi and Spinosad against corn pests under laboratory and field conditions in Egypt. Annual Research \& Review in Biology, 3, 903-912. https://doi.org/10.9734/arrb/2013/v3i424952 
Santos, A. C. S., Oliveira, R. L. S., Costa, A. F., Tiago, P. V., \& Oliveira, N. T. (2015). Controlling Dactylopius opuntiae with Fusarium incarnatum-equiseti species complex and extracts of Ricinus communis and Poincianella pyramidalis. Journal of Pest Science, 89(2), 539-547. https://doi.org/10.1007/s10340-0150689-4

Santos, D. C., Farias, I., Lira, M. A., Santos, M. V. F., Arruda, G. P., Coelho, R. S., ... Melo, J. N. (2006). Manejo e utilização da palma forrageira (Opuntia e Nopalea) em Pernambuco. Empresa Pernambucana de Pesquisa Agropecuária-IPA, Recife. Retrieved from http://www.ipa.br/publicacoes_tecnicas/Pal01.pdf

SAS Institute. (1999-2001). SAS user's guide: Statistics, Version 8.2 (6th ed.). Cary, NC: SAS Institute.

Silva, D. M. P., Mergulhão, A. C. E. S., Medeiros, L. V., Figueiredo, M. V. B., \& Burity, H. A. (2013). Genetic variability of Dactylopius opuntiae (Hemiptera, Dactylopiidae) on forage cactus in northeast Brazil. Genetics and Molecular Research, 12(4), 5236-5246. https://doi.org/10.4238/2013.October.30.8

Souza, M. C. C., \& Trovão, D. M. B. M. (2009). Bioatividade do extrato seco de plantas da Caatinga e do Nim (Azadiractha indica) sobre Sitophilus zeamais Mots em milho armazenado. Revista Verde de Agroecologia e Desenvolvimento Sustentável, 4(1), 120-124. Retrieved from https:/www.gvaa.com.br/revista/index.php/ RVADS/article/view/158/158

St. Leger, R. J., \& Wang, C. (2010). Genetic engineering of fungal biocontrol agents to achieve greater efficacy against insect pests. Applied Microbiology and Biotechnology, 85(4), 901-907. https://oi.org/10.1007/ s00253-009-2306-Z

Svedese, V. M., Tiago, P. V., Bezerra, J. D. P., Paiva, L. M., Alves-Lima, E. A. L., ... Porto, A. L. F. (2013). Pathogenicity of Beauveria bassiana and production of cuticle-degrading enzymes in the presence of Diatraea saccharalis cuticle. African Journal of Biotechnology, 12(46), 6491-6497. https://doi.org/ 10.5897/AJB2013.11972

Vázquez-García, M., Garabito-Espinoza, S., Tabares-Vega, J., \& Castillo-Herrera, G. (2011). Essential oils from aromatic plant species and insecticidal effects on Dactylopius opuntiae (Cockerell) (Homoptera: Dactylopiidae) in mobile juveniles. Acta Horticulturae, 894, 215-223. https://doi.org/10.17660/ActaHortic. 2011.894.24

Vigueras, A. L., Tovar, J. C., \& Pelayo-Ortiz, C. (2009). Use of botanicals extracts to control wild cochineal (Dactylopius opuntiae Cockerell) on Cactus Pear. Acta Horticulturae, 811(1), 299-234. https://doi.org/ 10.17660/ActaHortic.2009.811.28

Zhang, Y., Zhao, J., Fang, W., Zhang, J, Luo, Z., Zhang, M., ... Pei, Y. (2009). Mitogen-activated protein kinase hog1 in the entomopathogenic fungus Beauveria bassiana regulates environmental stress responses and virulence to insects. Applied and Environmental Microbiology, 75(11), 3787-3795. https://oi.org/10.1128/ AEM.01913-08

\section{Copyrights}

Copyright for this article is retained by the author(s), with first publication rights granted to the journal.

This is an open-access article distributed under the terms and conditions of the Creative Commons Attribution license (http://creativecommons.org/licenses/by/4.0/). 